Original Article

\title{
Use of Human Granulocyte Colony-Stimulating Factor (G-CSF) in Consolidation Chemotherapy in Adult Acute Myeloid Leukaemia (AML)
}

\author{
*Rumi MSIS ${ }^{1}$, Yunus $\mathrm{ABM}^{2}$, Kabir $\mathrm{AL}^{3}$, Begum $\mathrm{M}^{4}$, Irshadullah $\mathrm{NM}^{5}$, Wasim $\mathrm{M}^{6}$, Chowdhury $\mathrm{MSZ}^{7}$, \\ Hossain $\mathrm{MM}^{8}$, Rahman $\mathrm{MS}^{9}$, Islam $\mathrm{KA}^{10}$, Hasan $\mathrm{MN}^{11}$
}

\begin{abstract}
Acute myeloid leukaemia (AML) is treatable and potentially curable disease. Significant morbidity is related to the prolonged, severe neutropenia resulting from the disease as well as the intensive chemotherapy. The administration of granulocyte - colony stimulating factor (G-CSF) is recommended to reduce the neutropenic period. But the current information and guidelines are insufficient about the most appropriate time to start G-CSF and the optimum duration of treatment after chemotherapy in consolidation phase. This study explores better timing to start G-CSF after completion of chemotherapy in consolidation phase of AML patient. This prospective study was conducted in the department of Haematology, Bangabandhu Sheikh Mujib Medical University among AML patients, who received consolidation chemotherapy (high dose cytarabine).
\end{abstract}

1. ${ }^{*}$ Dr. Muhammad Shahidul Islam Sikder Rumi, MD (Haematology), Bangabandhu Sheikh Mujib Medical University (BSMMU) Shahbagh, Dhaka.

E-mail: drmuhammadrumi@gmail.com

2. Dr. A.B.M. Yunus, Professor, Department of Haematology, BSMMU, Shahbagh, Dhaka.

3. Dr. Amin Lutful Kabir, Associate Professor, Department of Haematology, BSMMU, Shahbagh, Dhaka.

4. Dr. Masuda Begum, Professor, Department of Haematology, BSMMU, Shahbagh, Dhaka.

5. Dr. Naseeb Muhammad Irshadullah, MD (Haematology), BSMMU, Shahbagh, Dhaka.

6. Dr. Mohammed Wasim, MD (Haematology), BSMMU, Shahbagh, Dhaka.

7. Dr. Md. Sazzad Zayed Chowdhury, MD (Haematology), BSMMU, Shahbagh , Dhaka.

8. Dr. Mohammed Murad Hossain, MD (Haematology), BSMMU, Shahbagh , Dhaka.

9. Dr. Md. Shafiur Rahman, MD Phase-B resident, Department of Haematology, BSMMU, Shahbagh, Dhaka.

10. Dr. Khaza Amirul Islam, MD Phase-B resident, Department of Haematology, BSMMU, Shahbagh, Dhaka.

11. Dr. Nazmul Hasan, Assistant Professor, Department of Internal Medicine, BSMMU, Shahbagh, Dhaka.

* For correspondence
Samples were grouped into two arms. Arm-A (Absolute Neutrophil Count $>1000 / \mathrm{cmm}$ ) received prophylactic G-CSF and Arm-B (Absolute Neutrophil Count $<1000 / \mathrm{cmm}$ ) received G-CSF during neutropenia. Filgrastim was used as $G$-CSF and daily 300 micrograms were given subcutaneously according to study protocol. Statistical analysis was done by parametric (t test) test and appropriate using computer based SPSS (21) Program. Total sample was 19, out of which 6 in prophylactic G-CSF group (Arm-A) and 13 in delayed $G$-CSF group (Arm-B). Most of the patients were male (63.16\%), male to female ratio 1.7:1 and mean age of sample 35 years. Mean ANC at the 1st day of G-CSF application in Arm-A 1170.5/cmm \& in Arm-B 272.6/cmm ( $p=<0.001$ ); mean requirements of G-CSF accordingly 11.5 and 5.9 ( $p=0.0014)$, mean 1st day of G-CSF application 9.5th day and 14.5th day ( $p=0.001$ ). Outcomes in Arm-A and Arm-B were accordingly, mean duration of $A N C$ recovery 10 and 9.85 days ( $p=0.913$ ), febrile neutropenia 2.67 and 2.57 days $(p=0.961)$, hospital stay 20 and 20.3 days $(p=0.259)$, red cell concentrate transfusion 1.83 and 1.46 units $(p=0.550)$, platelets concentrate transfusion 11.83 and 7.77 bags $(p=0.2405)$, and there was no death case in two arms. Differences of timing to start G-CSF and its requirements between two groups were significant, but the outcomes did not show any statistically significant difference.

Keywards: Acute myeloid leukaemia, consolidation, neutropenia, granulocyte colony-stimulating factor

\section{INTRODUCTION}

The global burden from cancer is rising. According to world health organisation (WHO), Bangladesh is experiencing increasing cancer burden with estimated 122,715 new cancer cases in 2012. Haematological malignancies comprise approximately $6.5 \%$ of all cancer incidences worldwide in 2012. ${ }^{1}$ Hossain et al. published a multi-centre hospital-based retrospective descriptive study of Bangladesh over 5000 confirmed haematological cancer cases in between January 2008 to December 2012. ${ }^{2}$ In this study Acute Myeloid Leukaemia was most frequent $(28.3 \%)$ with a median age of 35 years. 
Acute myeloid leukaemia (AML) is a cancer of the myeloid line of blood cells, characterized by the rapid growth of abnormal white blood cells that accumulate in the bone marrow and interfere with the production of normal blood cells. AML is the most common acute leukaemia affecting adults, and its incidence increases with age. ${ }^{3}$

AML is a treatable and potentially curable disease with intensive chemotherapy accompanied by recent improvements in supportive care. ${ }^{4}$ In a recent Cancer and Leukaemia Group B (CALGB) study, $44 \%$ of patients less than 60 years of age who achieved complete remission (CR) with standard cytosine arabinoside (Ara-C) and daunorubicin chemotherapy and subsequently received up to four courses of post remission consolidation chemotherapy with high-dose cytosine arabinoside (HiDAC), were estimated to remain in disease free condition at 5 years. ${ }^{5}$ Barriers to achieve higher rate of cure in AML include drug-resistant leukaemia, extramedullary toxicity from chemotherapeutic drugs, and prolonged pancytopenia due to ablative chemotherapy. ${ }^{6}$

Remission induction and consolidation treatment for acute myeloid leukaemia (AML) is associated with considerable morbidity and mortality. ${ }^{7,8}$ A significant morbidity is related to the prolonged, severe neutropenia resulting from the disease as well as the intensive chemotherapy. The outcome of treatment is dependent, in part, on the ability of patients to tolerate the myelosuppression and its consequences. ${ }^{9}$ Incidence of febrile neutropenia in consolidation phase is more than $85 \% .{ }^{10}$ The current ASCO guidelines justified the administration of colony stimulating factor (CSF) in clinical settings where the expected risk of suffering from febrile neutropenia (FN) is approximately $20 \% .^{11}$

G-CSF is a naturally occurring cytokine that stimulates the proliferation and differentiation of haemopoietic stem and progenitor cells committed to the neutrophil and granulocyte lineages. Fully differentiated neutrophilic granulocytes are functionally activated by G-CSF. ${ }^{12}$

Two forms of recombinant human G-CSF are available for clinical use - filgrastim and lenograstim. Both are produced by recombinant DNA technology. Filgrastim is produced in Escherichia coli whereas lenograstim is derived from Chinese hamster ovary cells. Available data do not suggest a clinically remarkable difference between filgrastim and lenograstim in chemotherapy-induced neutropenia and the mobilisation of peripheral blood progenitor cells in patients and healthy donors. ${ }^{13}$
Depth and duration of neutropenia correlate with the risk and severity of infection. ${ }^{14}$ So reducing the frequency and severity of neutropenia is considered a clinically relevant end point. This premise has been used to justify the administration of G-CSF. But the current data is not sufficient to indicate regarding the most appropriate time to start G-CSF and the optimum duration of treatment after consolidation chemotherapy of AML patient to reduce neutropenic events. ${ }^{15}$

\section{MATERIALS AND METHODS}

This is a prospective observational study. This study was done at the department of Haematology, Bangabandhu Sheikh Mujib Medical University, Shahbag, Dhaka, Bangladesh. Study period for this study was from October, 2014 to March, 2016. Study population were the AML patients in Complete Remission admitted to Haematology Department for consolidation phase with high dose Cytarabine (HiDAC, $3000 \mathrm{mg} / \mathrm{m}^{2}$ ). AML patients, who completed consolidation chemotherapy with HiDAC, satisfying inclusion and exclusion criteria, were included to this study. Confounding variables such as antibiotic therapy also were matched. Samples were grouped into two arms. Arm-A (ANC> 1000/cmm) received prophylactic G-CSF and Arm-B (ANC <1000/cmm) received G-CSF during neutropenia. Filgrastim was used as G-CSF and daily dose was 300 micrograms subcutaneously; and it will be continued up to neutrophil recovery (Absolute neutrophil count 19/L for 2 consecutive days). Purposive sampling was done. AML patients who have completed consolidation chemotherapy with HiDAC, aged between 18-60 years, Total WBC count $4000-11000 / \mathrm{cmm}$ and ANC>1000/cmm in peripheral blood before starting chemotherapy were taken. Informed written consent by the patient/party was taken. Patients with Acute promyelocytic leukaemia $\left(\mathrm{AML} \mathrm{M}_{3}\right)$ and body weight $<35 \mathrm{~kg}$ or $>80 \mathrm{~kg}$ were excluded from this study. Statistical analysis was done by parametric ( $\mathrm{t}$ test) test and appropriate using computer based SPSS (21) Program.

\section{RESULTS}

During 17 months study period, since October 2014March 2016, a total number of 19 patients who achieved complete remission after induction chemotherapy and then received consolidation chemotherapy with high dose cytarabine were analyzed. During each consolidation phase after finishing last dose of chemotherapy these patients were treated with G-CSF to reduce neutropenic period, neutropenic fever and hospital stay. G-CSF was 
given at least 72 hours later of last dose chemotherapy. Six (6) patients received prophylactic G-CSF (Arm-A) before development of neutropenia while ANC>1000/cmm and thirteen (13) patients received delayed G-CSF (Arm-B) during neutropenic period while $\mathrm{ANC}<1000 / \mathrm{cmm}$. After then outcomes were observed. Out of the 19 patients in the study, maximum was male $(63.16 \%)$ and remaining (36.84\%) patients were female. Male female ratio was 1.7:1. Patients ranged from 18-60 years. In Arm-A male were $3 \&$ their age range 19-42 years; female were $3 \&$ their age range $27-55$ years. In Arm-B male were $9 \&$ their age range 18-57 years; female were $4 \&$ their age range 18-27. Among total 19 patients, 9 patients (47.37\%) were in the range of $18-30$ years, 3 patients $(15.79 \%)$ were in the range of $31-45$ years and the remaining 7 patients $(36.84 \%)$ were in range of $46-60$ years. Mean $( \pm S D)$ ANC at $1^{\text {st }}$ day of G-CSF application in Arm-A was $1170.50 / \mathrm{cmm}$ $( \pm 207.37)$ and Arm-B 272.62/cmm $( \pm 232.05)$. P value was $<0.0001$ and significant as $\mathrm{p}<0.05$ (Table I).

Table I: Distribution of ANC at $\mathbf{1}^{\text {st }}$ day of G-CSF application

\begin{tabular}{|l|c|c|}
\hline Group & $\begin{array}{c}\text { Mean } \\
( \pm \text { SD })\end{array}$ & $\begin{array}{c}\text { P } \\
\text { value }\end{array}$ \\
\hline Arm-A & $\begin{array}{c}1170.50 \\
( \pm 207.37)\end{array}$ & $<0.0001$ \\
\hline Arm-B & $\begin{array}{c}272.62 \\
( \pm 232.05)\end{array}$ & \\
\hline
\end{tabular}

First day of G-CSF application was counted from $1^{\text {st }}$ day of chemotherapy. Mean $( \pm S D) 1^{\text {st }}$ day of G-CSF application in Arm-A was $9.5^{\text {th }}$ day $( \pm 1.22)$ and Arm-B $14.5^{\text {th }}$ day $( \pm 2.96)$. $P$ value was 0.001 and significant as $\mathrm{p}<0.05$ (Table II).

Table II: Distribution of 1 st day of G-CSF application

\begin{tabular}{|l|c|c|}
\hline Group & $\begin{array}{c}\text { Mean } \\
( \pm \text { SD })\end{array}$ & $\begin{array}{c}\text { P } \\
\text { value }\end{array}$ \\
\hline Arm-A & $\begin{array}{c}9.5 \\
( \pm 1.22)\end{array}$ & 0.001 \\
\hline Arm-B & $\begin{array}{c}14.5 \\
( \pm 2.96)\end{array}$ \\
\hline
\end{tabular}

Mean $( \pm S D)$ of G-CSF requirement in Arm-A was 11.5 $( \pm 3.56)$ and Arm-B $5.92( \pm 2.69)$. P value was 0.0014 and significant as $\mathrm{p}<0.05$ (Table III).
Table III: G-CSF requirement

\begin{tabular}{|l|c|c|}
\hline Group & $\begin{array}{c}\text { Mean } \\
( \pm S D)\end{array}$ & $\begin{array}{c}\text { P } \\
\text { value }\end{array}$ \\
\hline Arm-A & $\begin{array}{c}11.5 \\
( \pm 3.56)\end{array}$ & 0.0014 \\
\hline Arm-B & $\begin{array}{c}5.92 \\
( \pm 2.69)\end{array}$ & \\
\hline
\end{tabular}

First day of neutropenia was counted from $1^{\text {st }}$ day of chemotherapy. Mean $( \pm S D) 1^{\text {st }}$ day of neutropenia which developed after chemotherapy in Arm-A was $11^{\text {th }}$ day $( \pm 1.55)$ and Arm-B $11.46^{\text {th }}$ day $( \pm 2.57)$. P value was 0.6914 and this value was not significant as $\mathrm{p}>0.05$ (Table IV).

Table IV: Distribution of first day of neutropenia after chemotherapy

\begin{tabular}{|l|c|c|}
\hline Group & $\begin{array}{c}\text { Mean } \\
( \pm \text { SD })\end{array}$ & $\begin{array}{c}\text { P } \\
\text { value }\end{array}$ \\
\hline Arm-A & $\begin{array}{c}11 \\
( \pm 1.55)\end{array}$ & 0.6914 \\
\hline Arm-B & $\begin{array}{c}11.46 \\
( \pm 2.57)\end{array}$ & \\
\hline
\end{tabular}

Duration of ANC recovery was counted from $1^{\text {st }}$ day of neutropenia after chemotherapy to neutrophil count recovery. Mean $( \pm \mathrm{SD})$ days needed to recover in Arm-A was 10 days $( \pm 3.85)$ and Arm-B 9.85 days ( \pm 2.23$)$. P value was 0.913 and this value was not significant as $\mathrm{p}>0.05$ (Table V).

Table V: Distribution of ANC recovery period

\begin{tabular}{|l|c|c|}
\hline Group & $\begin{array}{c}\text { Mean } \\
( \pm \text { SD })\end{array}$ & $\begin{array}{c}\text { P } \\
\text { value }\end{array}$ \\
\hline Arm-A & $\begin{array}{c}10 \\
( \pm 3.85)\end{array}$ & 0.913 \\
\hline Arm-B & $\begin{array}{c}9.85 \\
( \pm 2.23)\end{array}$ \\
\hline
\end{tabular}

Out of the 6 patients in Arm-A 3 (50\%) patients developed neutropenic fever and out of 13 patients in Arm-B 7 (53.85\%) patients developed neutropenic fever (Table VI). 
Table VI: Distribution of neutropenic fever $(n=10)$

\begin{tabular}{|l|c|c|}
\hline Group & Frequency & Percentage \\
\hline Arm-A & 3 (out of 6) & 50.0 \\
\hline Arm-B & 7 (out of 13) & 53.85 \\
\hline
\end{tabular}

Mean $( \pm S D)$ duration of neutropenic fever in Arm-A was 1.33 days $( \pm 1.97)$ and Arm-B 1.38 days $( \pm 2.23)$. P value was 0.965 and this value was not significant as $p>0.05$ (Table VII).

Table VII: Duration of neutropenic fever

\begin{tabular}{|l|c|c|}
\hline Group & $\begin{array}{c}\text { Mean } \\
( \pm \text { SD })\end{array}$ & $\begin{array}{c}\text { P } \\
\text { value }\end{array}$ \\
\hline Arm-A & $\begin{array}{c}1.33 \\
( \pm 1.97)\end{array}$ & 0.965 \\
\hline Arm-B & $\begin{array}{c}1.38 \\
( \pm 2.47)\end{array}$ & \\
\hline
\end{tabular}

Duration of hospitalization was counted from first day of chemotherapy to neutrophil count recovery. Mean $( \pm S D)$ duration of hospital stay in Arm-A was 20 days ( \pm 3.35 ) and Arm-B 20.3 days $( \pm 1.89)$. P value was 0.259 and this value was not significant as $\mathrm{p}>0.05$ (Table VIII).

Table VIII: Distribution of hospital stay

\begin{tabular}{|l|c|c|}
\hline Group & $\begin{array}{c}\text { Mean } \\
( \pm \text { SD })\end{array}$ & $\begin{array}{c}\text { P } \\
\text { value }\end{array}$ \\
\hline Arm-A & $\begin{array}{c}20 \\
( \pm 3.35)\end{array}$ & 0.259 \\
\hline Arm-B & $\begin{array}{c}20.3 \\
( \pm 1.89)\end{array}$ & \\
\hline
\end{tabular}

Mean $( \pm S D)$ of platelet concentrate requirement in Arm- $A$ was $11.83( \pm 9.22)$ and Arm-B $7.77( \pm 5.43)$. P value was 0.2405 and this value was not significant as $\mathrm{p}>0.05$ (Table IX).

Table IX: Platelet concentrate requirement

\begin{tabular}{|l|c|c|}
\hline Group & $\begin{array}{c}\text { Mean } \\
( \pm S D)\end{array}$ & $\begin{array}{c}\mathrm{P} \\
\text { value }\end{array}$ \\
\hline Arm-A & $\begin{array}{c}11.83 \\
( \pm 9.22)\end{array}$ & 0.2405 \\
\hline Arm-B & $\begin{array}{c}7.77 \\
( \pm 5.43)\end{array}$ & \\
\hline
\end{tabular}

Mean $( \pm$ SD) requirement of red cell concentrate in Arm-A was $1.83( \pm 1.60)$ and Arm-B $1.46( \pm 1.05)$. P value was 0.550 and this value was not significant as $\mathrm{p}>0.05$ (Table $\mathrm{X})$.

Table X: Red cell concentrate requirement

\begin{tabular}{|l|c|c|}
\hline Group & $\begin{array}{c}\text { Mean } \\
( \pm \mathrm{SD})\end{array}$ & $\begin{array}{c}\text { P } \\
\text { value }\end{array}$ \\
\hline Arm-A & $\begin{array}{c}1.83 \\
( \pm 1.60)\end{array}$ & 0.550 \\
\hline Arm-B & $\begin{array}{c}1.46 \\
( \pm 1.05)\end{array}$ & \\
\hline
\end{tabular}

There was no death both in Arm-A and Arm-B.

\section{DISCUSSION}

This study was done to understand better timing of G-CSF starting after chemotherapy in consolidation phase of adult AML patients.

In this study, differences between two arms in ANC of G-CSF application by $898 / \mathrm{cmm} \quad(1170.50 / \mathrm{cmm} \quad$ vs $272.6 / \mathrm{cmm} ; \mathrm{P}=<0.0001)$; timing difference of $\mathrm{G}-\mathrm{CSF}$ application by 5 days $\left(9.5^{\text {th }}\right.$ day vs $14.5^{\text {th }}$ day; $\left.\mathrm{P}=0.001\right)$; and total need of G-CSF by 5.6 (11.5 G-CSF vs 5.92 $\mathrm{G}-\mathrm{CSF} ; \mathrm{P}=0.0014)$; were significant.

The outcomes such as neutropenic period (10 days vs 9.85 days; $\mathrm{P}=0.91$ ); duration of febrile days during neutropenia ( 1.33 days vs 1.38 days; $\mathrm{P}=0.96$ ); hospital stay ( 20 days vs 20.3 days; $\mathrm{P}=0.259$ ); and first day of neutropenia (11th days vs 11.46 days; $\mathrm{P}=0.69$ ) revealed no statistically significant differences.

Moreover, mean platelet concentrates (11.83 units vs 7.77 units) and mean red cell concentrates (1.83 units vs 1.46 units) requirement also were more in prophylactic G-CSF group than delayed G-CSF group. Comparison of above findings between different age and sex groups were not focused as it failed to reveal any statistically significant value.

Above findings also correlate with the study of Marie VLT et al. ${ }^{16}$ They included sixty-six patients receiving induction chemotherapy. Patients were randomized as follows: Group A received filgrastim from day 6 and group B from day 12. The dose was $480 \mu \mathrm{g} / \mathrm{d}$ if $>75 \mathrm{~kg}$ and $300 \mu \mathrm{g} / \mathrm{d}$ if $\leq 75 \mathrm{~kg}$. There was no difference in duration of neutropenia (17 days vs. 19 days, $\mathrm{p}=0.67$ ) or rate of complications. ${ }^{17}$ 
Red cell concentrates and platelet concentrates requirement were more in prophylactic group probably due to more use of G-CSF. These findings correlate with the study of Papaldo et al. ${ }^{18}$, Wexler LX and Stroncek DF et al. ${ }^{19}$

Papaldo et al. reported on the effects of G-CSF on haemoglobin in 506 patients with stage I-II breast cancer who received adjuvant epirubicin and cyclophosphamide (EC) at $120 \mathrm{mg} / \mathrm{m}^{2}$ and $600 \mathrm{mg} / \mathrm{m}^{2}$. Overall the study showed that anaemia was higher in the G-CSF group than in the controls ( $38.8 \%$ vs. $26.2 \%, \mathrm{P}<0.005) .{ }^{18}$

In the study of Wexler LX thirty-seven newly diagnosed cases age 1 to 25 years were randomized to receive 18 cycles of chemotherapy alone or with GM-CSF. GM-CSF was associated with more severe and protracted thrombocytopenia; median platelet nadir 29,500/micro litre (range 3,000 to 288,000 ) vs. 59,000/micro litre (range 3,000 to 309,000$), \mathrm{P}<0.0001$; median time to recovery (> 75,000/microlitre) 16.0 days (range, 0 to 61) vs. 14.0 days (range 0 to 38 ), $\mathrm{P}<0.0001$ (significant). ${ }^{19}$

In the study of Stroncek DF et al. no significant decrease in platelet counts was noted after administering G-CSF for 5 days, but individuals who received 10 days of G-CSF showed a close to $30 \%$ decrease from pre treatment platelet values prior to the aphaeresis. ${ }^{20}$

Above discussion gives information that prophylactic G-CSF (i.e G-CSF started before development of neutropenia) failed to show better outcomes than delayed G-CSF in consolidation phase of AML.

\section{CONCLUSIONS}

In the light of the discussion, the following conclusions and recommendations are made to understand the better timing to start G-CSF after chemotherapy in consolidation phase of AML patient.

Different guidelines recommended for using G-CSF in consolidation phase of AML and it can be started 24-72 hours after last dose of chemotherapy. This study evaluated the timing to start G-CSF on duration of G-CSF use, duration of hospitalization, duration of neutropenia and number of febrile days in AML patients.

Both prophylactic G-CSF group and delayed G-CSF group showed no statistically significant difference on neutropenic period, febrile days, neutrophil recovery, hospitalization, red cell concentrate and platelet concentrate transfusion. Rather early administration of
G-CSF associated with more use of G-CSF as well as more need of red cell concentrate and platelet concentrate transfusion, which in turn increase the total treatment cost.

In conclusion, administration of G-CSF can be delayed to nine days or upto $270 / \mathrm{cmm}$ of ANC after the end of chemotherapy without a prolonged duration of neutropenia or other adverse effects. Prospective, controlled studies are needed to support these findings.

\section{REFERENCES}

1. Ferlay J, Soerjomataram I, Ervic M, Dikshit R, Eser S, Mathers C, Rebelo M, Parkin DM, Bray F. Cancer incidence, mortality and prevalence worldwide in 2012, GLOBOCAN. Retrived March 26, 2016 from http:// globocan.iarc.fr/ Default.aspx 2013.

2. Hossain MS, Iqbal MS, Khan MA, Rabbani MG, Khatun H, Munira S, Miah MM, Kabir AL, Islam N, Dipta TF, Rahman F. Diagnosed hematological malignancies in Bangladesh-a retrospective analysis of over 5000 cases from 10 specialized hospitals. BMC cancer. 2014 Dec; 14(1):438.

3. Jemal A, Thomas A, Murray T, Thun M. Cancer statistics, 2002. Ca-A Cancer Journal for Clinicians. Jan 1; 52(1):23-47.

4. Joseph O, Moore, Richard K et al. Granulocyte colony-stimulating factor (filgrastim) accelerates granulocyte recovery after intensive postremission chemotherapy for acute myeloid leukemia with aziridinyl benzoquinone and mitoxantrone: Cancer and Leukemia Group B study 9022. Blood 1996 Feb 1; 88(3):780-8.

5. Mayer RJ, Davis RB, Schiffer CA, Berg DT, Powell BL, Schulman P, Omura GA, Moore JO, McIntyre OR, Frei E. Intensive postremission chemotherapy in adults with acute myeloid leukemia. New England Journal of Medicine. 1994 Oct 6; 331(14):896-903.

6. Moore JO, Dodge RK, Amrein PC, Kolitz J, Lee EJ, Powell B, Godfrey S, Robert F, Schiffer CA. Granulocyte colony-stimulating factor (filgrastim) accelerates granulocyte recovery after intensive postremission chemotherapy for acute myeloid leukemia with aziridinyl benzoquinone and mitoxantrone: Cancer and Leukemia Group B study 9022. Blood. 1997 Feb 1; 89(3):780-8.

7. Sebban C, Archimbaud E, Coiffier B, Guyutat D, Treille-Ri-touet D, Maupas J. Treatment of acute 
myeloid leukaemia in elderly patients, A retrospective study. Cancer 1998; 61:227.

8. Rees JK, Swirsky D, Gray RG, Hayhoe FG. Principal results of the Medical Research Council's 8th acute myeloid leukaemia trial. The Lancet. 1986 Nov 29; 328(8518):1236-41.

9. Stone RM, Mayer RJ. The approach to the elderly patient with acute myeloid leukaemia, Haematol Oncol Clin North Am 1993; 7:65.

10. Allan DS et al. Outpatient supportive care following chemotherapy for acute myeloblastic leukaemia. Leuk Lymphoma 2001; 42(3):339-46

11. Smith TJ, Khatcheressian J, Lyman GH, Ozer H, Armitage JO, Balducci L, Bennett CL, Cantor SB, Crawford J, Cross SJ, Demetri G. 2006 update of recommendations for the use of white blood cell growth factors: an evidence-based clinical practice guideline. Journal of Clinical Oncology. 2006 Jul 1; 24(19):3187-205.

12. Gomez RC, Pinto MA, Gonzalez BM, Colony-stimulating factor: clinical evidence for treatment and prophylaxis of chemotherapy-induced febrile neutropenia, Clin Trans Oncoln 8:729-34

13. Sourgens H, Lefrère F. A systematic review of available clinical evidence-filgrastim compared with lenograstim. International journal of clinical pharmacology and therapeutics. 2011 Aug; 49(8): 510-8.

14. Bodey GP, Buckley M, SATHE Y, Freireich EJ. Quantitative relationships between circulating leukocytes and infection in patients with acute leukemia. Annals of internal medicine. 1966 Feb 1; 64(2):328-40.

15. Kent \& Medway Cancer Network. 2013, Guidelines for use of G-CSF in adult haematology and oncology patients. Retrived January 20, 2015, from http://www.kentmedwaycancernetwork.nhs.uk/hom e-page/for-professionals/

16. Marie VLT, Corinna HA, Hartmut K, Dimitri F, Gottfried D, Axel G. A randomized comparison of immediate versus delayed application of G-CSF in induction therapy for patients with acute myeloid leukemia unfit for intensive chemotherapy. Haematologica.2007 Dec; 92(12):1719-20.

17. Raposo CG, Marín ÁP, Barón MG. Colonystimulating factors: clinical evidence for treatment and prophylaxis of chemotherapy-induced febrile neutropenia. Clinical and Translational Oncology. 2006 Oct 1; 8(10):729-34.

18. Papaldo P, Ferretti G, Di Cosimo S, Giannarelli D, Marolla P, Lopez M, Cortesi E, Antimi M, Terzoli E, Carlini P, Vici P. Does granulocyte colonystimulating factor worsen anemia in early breast cancer patients treated with epirubicin and cyclophosphamide? Journal of clinical oncology. 2006 Jul 1; 24(19):3048-55.

19. Wexler LH, Weaver-McClure L, Steinberg SM, Jacobson J, Jarosinski P, Avila N, Pizzo PA, Horowitz ME. J Clin Oncol. 1996 Mar; 14(3):901-10.

20. Stroncek DF, Rebulla P. Platelet transfusions. The Lancet. 2007 Aug 4;370(9585):427-38. 